\title{
Impact of Dumping of Municipal Solid Waste on Households Near Dumping Yard in Karnataka, India
}

\author{
Shilpa P. Chowti ${ }^{1}$, G.N. Kulkarni ${ }^{1}$ and M.V. Manjunatha ${ }^{2 *}$ \\ ${ }^{1}$ Department of Agricultural Economics, ${ }^{2}$ Department of Agricultural Engineering \\ College of Agriculture, Dharwad, University of Agricultural Sciences, \\ Dharwad-580 005, Karnataka, India \\ *Corresponding author
}

\begin{tabular}{|l|}
\hline Ke y w o r d s \\
Solid waste, \\
Dumping yard, \\
Health problems, \\
Asthma
\end{tabular}

\section{Introduction}

Environmental pollution includes air pollution, water pollution and land pollution. Solid waste is not just deleterious to a single part of environment but to the whole environment. Solid waste problem surpasses traditional environmental boundaries and augment air, water as well as land pollution. It is the most visible form of environmental problem in many urban regions. The increased generation in solid waste and diversification in solid waste generation is attributed to many factors such as rising population, changing income, consumption pattern, economic development, urbanization and 
industrialization. Solid waste describes nonliquid materials accumulated from domestic, trade, commercial, agricultural and intensive industrial activities including from public services.

In the process of solid waste management, the proper and safe disposal of solid waste is the final stage. Uncontrolled and unscientific disposal of all categories of waste in urban areas has led to the environmental problems such as contamination of land, water and environment. Apart from environmental pollution, there are potential risks to human health from improper handling of solid waste. The workers in the field of solid waste management have direct health risks, who need to be protected from direct contact with waste. For the general public, the main health risks are indirect and arise from the breeding of disease vectors, primarily flies and rats. Indiscriminate dumping of wastes contaminates surface and ground water supplies. In urban areas, municipal solid waste clogs drains, creating stagnant water for insect breeding and floods during rainy seasons. Health and safety issues also arise from improper municipal solid waste management. Insect and rodent vectors are attracted to the waste and they spread diseases such as cholera and dengue fever.

Unfortunately, the solid wastes management has received very little attention in the country which resulted in to unsanitary conditions in almost all cities and towns. The main reason behind this could be lack of awareness and responsibility of both concerned authorities as well as citizens. Most of the citizens haphazardly dispose solid waste generated on the street drains as well as in the public places. Most of the management services can be done through the application of waste hierarchy which refers to the "3 Rs" Reduce, Reuse and Recycle. This hierarchy classifies waste management strategies according to their desirability in terms of waste minimization aimed at extracting the maximum practical benefits from products and to generate the minimum amount of waste (Arivukkarasu and Lakshmi, 2014). However, in most Indian cities, the Municipal Solid Waste Management (MSWM) system comprises only four activities namely waste generation, collection, transportation, segregation and disposal. Such a solid waste management requires heavy financial outlays for the local government bodies.

The most common method of solid waste disposal in most of the cities is dumping in an open area or land filling. In large towns and cities the availability of land for waste disposal is very limited (Ramachandra, 2009). In many places, a major fraction of urban wastes are directly disposed in low lying area or in hilly area at city outskirts (Chattopadhyay et al., 2009). However, landfilling or disposal is restricted to nonbiodegradable, inert waste and other wastes that are not suitable either for recycling or for biological processing as per MSW Rule, 2000. The two leading innovative mechanisms of waste disposal being adopted in India include composting (aerobic composting and vermi-composting) and waste-toenergy(WTE) (incineration, pelletisation, and bio-methanation).

WTE projects for disposal of MSW are relatively a new concept in India. Although these have been tried and tested in developed countries with positive results are yet to take off the ground in India and this is largely because of their financial viability and sustainability is still being tested. Keeping these in view, the study has been taken-up to study the solid waste management practices fallowed in selected corporations and the health impact on residents near dumping site due to dumping of solid waste 


\section{Study area}

The study was taken up in two cities of Karnataka state. The cities were selected based on the quantity of solid waste generated. For the purpose of the study, HubballiDharwad municipal corporation and Bruhat Bengaluru Mahanagara Palike were selected. Hubballi and Dharwad are the twin cities in the state of Karnataka, with a distance of 20 $\mathrm{km}$. The twin cities of Hubballi and Dharwad collectively referred to as "HubballiDharwad". Dharwad is the administrative headquarter of the Dharwad district. The city is governed by the Hubballi-Dharwad Municipal Corporation. The municipality of Hubballi-Dharwad (resulting from a merger in 1961 with its twin city Hubballi) covers an area of $200.23 \mathrm{~km}^{2}$ spread over 45 revenue villages. Hubballi-Dharwad Municipal Corporation is responsible for the civic infrastructure and administration of the twin cities of Hubballi and Dharwad, located in North Western part of Karnataka state. The organization is known, in short, as HDMC. This civic administrative body administers an area of $202.3 \mathrm{~km}^{2}$. The twin cities are currently divided into 67 wards.

Bengaluru Urban district came into existence in 1986, with the partition of the erstwhile Bengaluru district into Bengaluru Urban and Rural districts. The Bruhat Bengaluru Mahanagara Palike (BBMP) is the administrative body responsible for the civic and infrastructural assets of the Greater Bengaluru metropolitan area. The BBMP represents the third level of government, (Central government and State Government being the first two levels). Bruhat Bengaluru Mahanagara Palike is run by a city council. BBMP is divided into eight zones like East zone, West zone, South zone, RR Nagar zone, Mahadevapura zone, Bommanahalli zone, Dasarahalli zone and Yelahanka zone for the ease of administration each is administered by a Zonal Commissioner and every zone has a Joint Commissioner.

\section{Materials and Methods}

The present study was taken up in two selected municipal corporations (HDMC and BBMP) of Karnataka. The study was based on both primary and secondary data. For evaluating the objectives of the study, the households residing near solid waste disposal site and farmers using recycled solid waste category, a set of 30 sample respondents were selected, respectively under each municipal corporation. In total, 60 sample respondents were selected for analyzing the objectives of the study. The secondary data on quantity solid waste generation, collection and disposal was collected from reports of HDMC and BBMP. The primary data was collected through personal interview method with the help of pre-tested and well-structured schedule. The data collected pertained to the year 2016-17. The primary data was collected on education, family type, housing type, occupation, income, health status of the households and problems faced.

\section{Tabular presentation technique}

In order to draw meaningful interpretation and inferences the results are presented in tabular form and the descriptive statistics like averages, percentages, etc were used. The disposal methods practiced in both corporations, general characteristics of households near dumping yard and health impacts on them was presented in tabular form

\section{Garrett's ranking technique}

Garrett's ranking technique was used to identify the problems faced by households residing near dumping yard in the study area. Garrett ranking is applied to rank a set of items or factors as perceived by the sample 
respondents based on certain criteria. The order of merit assigned by the respondents was converted into scores using the formula

Per cent position of each rank $=$

$100(\mathrm{Rij}-0.5) / \mathrm{Nj}$

Where,

$\mathrm{Rij}=$ the rank of the $\mathrm{i}^{\text {th }}$ item by $\mathrm{j}^{\text {th }}$ individual and

$\mathrm{Nj}=$ the number of items ranked by the $\mathrm{j}^{\text {th }}$ individual.

By referring the Garrett's table, per cent position was estimated and converted into score. Then, for each factor the scores of various respondents were added and the mean score was calculated. The factor with the highest mean score was considered to be the most important constraint. Thus, mean score for each constraint was ranked by arranging them in the descending order.

\section{Results and Discussion}

\section{Disposal methods of municipal solid waste in Hubballi-Dharwad and Bengaluru}

Waste disposal is the final stage of solid waste management. Scientific and safe disposal of solid waste is the most important and crucial stage in the solid waste management and there are different ways of solid waste disposal but most commonly fallowed in most of the cities was open dumping. Table 1 represents disposal methods of municipal solid waste in Hubballi-Dharwad and Bengaluru cities. In Hubballi-Dharwad, method of solid waste disposal was mainly comprised of open dumping. Out of $400 \mathrm{t}$ of solid waste generated in the city, $390 \mathrm{t}$ of waste was dumped in two open dumping yards located in Hubballi and Dharwad on an area of 38 acres. The open dumping yard located within Dharwad (Hosayallapura) city has an area of
22 acres and receives about 270 t of solid waste every day and another dumping yard was located in Hubballi (Ayodhya village) with an area of 16 acres and receives about $120 \mathrm{t}$ of solid waste every day. In total, on an average 16 lakh tonne of solid wastes get accumulated in dumping yards every year.

In Bengaluru city, seven dumping yards namely Mandur North (750 t/day), Mandur South (1,500 t/day), Mavallipura (1,000 t/day), Anjanapura (200 t/day), Cheemasandra (300 t/day), Kannahalli (650 t/day) and Bingipura (600 t/day) were already closed. The total area utilized for solid waste disposal for all sites together was 390 acres and mixed waste was open dumped in these dumping yards. Out of the total solid waste generated in Bengaluru city, about $3200 \mathrm{t}$ of solid waste was land filled in three land filling sites. Bagalur land fill site receives about $900 \mathrm{t}$ of solid waste per day spread on an area of 53 acres while, Mitaganahalli and Bellahalli landfills receives $1,500 \mathrm{t}$ (61 acres) and $800 \mathrm{t}$ (45 acres) of solid waste per day, respectively. The total area utilized for land filling of municipal solid waste in three sites was 159 acres. The study on solid waste dump sites around Bangalore was carried out by Lakshmikantha (2006) who reported that the ground water around the dump site area was contaminated. It was found that the site required immediate attention and classified under severe impact category of 27 numbers and that of medium and low impact were with 18 and 6 numbers, respectively. Further, the disposal sites have proved tremendous potential of spreading the epidemics/diseases to the people living in their immediate vicinity and nearby places/areas.

\section{General characteristics of households near dumping yard}

In order to know the impact of open dumping/landfilling of solid waste on 
households residing near the dumping yard sites 30 respondents from each selected cities were interviewed to assess the impact. The general characteristics of the households near dumping yard are presented Table 2. This helped us to know the socio-economic background of these respondents and vulnerability of these residents and their living in unsafe environment and also to know the factors responsible for settlement near dumping yards. The average age of the respondents across Hubballi-Dharwad and Bengaluru was 43.63 years and 45.17 years, respectively indicated of younger group. The family size of respondents in twin cities was almost on par (4.33) and in Bengaluru (4.01). Majority of the respondents both in HubballiDharwad (73.33 \%) and Bengaluru (83.33\%) had nuclear family type while 26.67 per cent in Hubballi-Dharwad and 16.67 per cent in Bengaluru had joint family. This indicated of household inclination was more in favour of nuclear type family in recent years. With respect to educational status of respondents most of them were literates with primary education $(33.33 \%$ and $26.67 \%)$ and secondary education (26.67\% and $36.67 \%$ ) and college level education (26.67 \% and $16.67 \%$ ), respectively in Hubballi-Dharwad and Bengaluru. The education was important factor that determined the occupational pattern and this intern determine income of an individual. It was observed that most of the respondents were engaged in private service sector as contract labour in construction works and were daily wage earners thus, majority of them belonged to medium and low income groups in both cities under study.

It was evident from the results of the study that lower level of education and lower income level of the respondents were the major factors responsible for their settlement near dumping yards due to poor economic status. The respondents found to prefer the area near dumping yard for settlement due to availability of sites at lower price and majority of the respondents just acquired unoccupied Government area for construction of house. The average distance to dumping yard from their residence was just $100 \mathrm{~m}$ in HubballiDharwad and $300 \mathrm{~m}$ in Bengaluru. This indicated that they were residing just adjacent to dumping yards, frequent health problems were observed and were vulnerable to menacing health problems. Though, majority of the respondents were willing to change their residences way from dumping yards but was not feasible option for them as they already owned house and high cost of sites in other localities. While, the respondents stayed in the rented houses showed willingness to change their residence away from the dumping yards. Regarding precautionary measures initiated by municipals from time to time like regular spraying of chemicals to manage mosquitos, about 80.00 per cent and 73.33 per cent of respondents, respectively in HubballiDharwad and Bengaluru indicated that no such regular measures were taken to avoid harmful effects of open dumping of solid waste in their locality.

This indicated of poor attention towards these areas near dumping yards with respect to precautionary measures to protect from illeffects of solid waste dumping thus, indicated of negligence of municipal corporations especially, in case of open dumping adopted near residences in Hubballi-Dharwad since any decades.

\section{Health impacts on households near solid waste dumping yard}

The present study also intended to know the health impacts on households due to poor or unscientific disposal and dumping of solid waste near dwelling places. The present level of solid waste management services and its disposal pattern adopted in both the cities it could be very well said that such sites are 
serving as potential threat to public health and polluted the environment. In HubballiDharwad, disposal method adopted was open dumping for many decades which considered as the most unhygienic to people residing near dumping yards and also to the environment in the vicinity. In Bengaluru, landfilling of solid waste was practiced however was founded to be unscientifically carried thus, creating public health hazardous on the habitats. The long term exposure of population who resided in the area surrounding dumping sites has led to negative health impacts on people. The major health problems noticed in the area were prolonged asthma, nose irrigation and respiratory problems in adults and in case of children, frequent omitting, fever and malaria (Table 3).

Table.1 Disposal methods of municipal solid waste in Hubballi-Dharwad and Bengaluru

\begin{tabular}{|c|c|c|c|c|c|}
\hline $\begin{array}{l}\text { Sl. } \\
\text { No }\end{array}$ & Landfill sites & $\begin{array}{c}\text { Area } \\
\text { (acres) }\end{array}$ & $\begin{array}{c}\text { Quantity of } \\
\text { waste received } \\
(t / \text { day })\end{array}$ & $\begin{array}{l}\text { Waste management } \\
\text { methodology fallowed }\end{array}$ & Disposal method \\
\hline \multicolumn{6}{|c|}{ Hubballi-Dharwad twin cities (HDMC) } \\
\hline 1 & $\begin{array}{l}\text { Hosayallapur, } \\
\text { Dharwad }\end{array}$ & 22 & 270 & Mixed waste & Open dumping \\
\hline 2 & $\begin{array}{l}\text { Ayodhya village } \\
\text { Hubballi }\end{array}$ & 16 & 120 & Mixed waste & Open dumping \\
\hline & Total & 38 & 390 & & \\
\hline $\begin{array}{r}\text { Ave } \\
\text { w }\end{array}$ & $\begin{array}{l}\text { e quantity of solid } \\
\text { te dumped/year }\end{array}$ & & & 16 lakh tonnes & \\
\hline \multicolumn{6}{|c|}{ Bengaluru city (BBMP) } \\
\hline \multicolumn{6}{|c|}{ I. Closed } \\
\hline 1 & Mandur North & 95 & 750 & Mixed waste & Open dumping \\
\hline 2 & Mandur South & 135 & 1,500 & Mixed waste & Open dumping \\
\hline 3 & Mavallipura & 100 & 1,000 & Mixed waste & Open dumping \\
\hline 4 & Anjanapura & 5 & 200 & Mixed waste & Open dumping \\
\hline 5 & Cheemasandra & 10 & 300 & Mixed waste & Open dumping \\
\hline 6 & Kannahalli & 25 & 650 & Mixed waste & Open dumping \\
\hline 7 & Bingipura & 20 & 600 & Mixed waste & Open dumping \\
\hline & Total & 390 & 5,000 & & \\
\hline \multicolumn{6}{|c|}{ II. Operating } \\
\hline 1 & Bagalur & 53 & 900 & Mixed waste & Landfilling \\
\hline 2 & Mitaganhalli & 61 & 1,500 & Mixed waste & Landfilling \\
\hline 3 & Bellahalli & 45 & 800 & Mixed waste & Landfilling \\
\hline & Total & 159 & 3,200 & & \\
\hline \multicolumn{2}{|c|}{$\begin{array}{l}\text { Average quantity of solid } \\
\text { waste dumped/year }\end{array}$} & \multicolumn{4}{|c|}{24 lakh tonnes } \\
\hline
\end{tabular}


Table.2 General characteristics of households near dumping yard in Hubballi-Dharwad and Bengaluru cities

\begin{tabular}{|c|c|c|c|c|c|c|}
\hline \multirow[t]{2}{*}{$\begin{array}{l}\text { Sl. } \\
\text { No }\end{array}$} & \multirow[t]{2}{*}{ Particulars } & \multirow[t]{2}{*}{ Unit } & \multicolumn{2}{|c|}{$\begin{array}{l}\text { Huballi-Dharwad twin } \\
\text { cities }(\mathrm{n}=\mathbf{3 0})\end{array}$} & \multicolumn{2}{|c|}{$\begin{array}{c}\text { Bengaluru cities } \\
(\mathrm{n}=30)\end{array}$} \\
\hline & & & Average & Percentage & Average & Percentage \\
\hline 1 & Age of the respondents & Years & 43.63 & & 45.17 & \\
\hline \multirow[t]{4}{*}{2} & Size of the family & & 4.33 & & 4.01 & \\
\hline & Male & No. & 1.90 & 43.88 & 1.44 & 35.91 \\
\hline & Female & No. & 1.40 & 32.33 & 1.31 & 32.67 \\
\hline & Children & No. & 1.03 & 23.79 & 1.26 & 31.42 \\
\hline \multirow[t]{3}{*}{3} & Family type & & & & & \\
\hline & Joint family & No. & 8 & 26.67 & 5 & 16.67 \\
\hline & Nuclear family & No. & 22 & 73.33 & 25 & 83.33 \\
\hline \multirow[t]{5}{*}{4} & Education level & & & & & \\
\hline & Illiterates & No. & 4 & 13.33 & 6 & 20.00 \\
\hline & Primary & No. & 10 & 33.33 & 8 & 26.67 \\
\hline & Secondary & No. & 8 & 26.67 & 11 & 36.67 \\
\hline & College & No. & 8 & 26.67 & 5 & 16.67 \\
\hline \multirow[t]{4}{*}{5} & Occupational structure & & & & & \\
\hline & Government service & No. & 5 & 16.67 & 9 & 30.00 \\
\hline & Private service & No. & 17 & 56.67 & 15 & 50.00 \\
\hline & Business & No. & 8 & 26.67 & 6 & 20.00 \\
\hline \multirow[t]{7}{*}{6} & Average income of family & ₹/month & 25,976 & & & 31,435 \\
\hline & High income group & No. & 7 & 23.33 & 10 & 33.33 \\
\hline & (>₹30,000) & ₹/month & & 32,151 & & 36,876 \\
\hline & Medium income group & No. & 11 & 36.67 & 12 & 40.00 \\
\hline & (₹20,000-₹30,000) & ₹/month & & 24,432 & & 28,342 \\
\hline & Low income group & No. & 12 & 40.00 & 8 & 26.67 \\
\hline & $(<₹ 20,000)$ & ₹/month & & 18,768 & & 19,553 \\
\hline \multirow[t]{3}{*}{7} & Type of house & No. & & & & \\
\hline & Owned & & 20 & 66.67 & 11 & 36.67 \\
\hline & Rented & & 10 & 33.33 & 19 & 63.33 \\
\hline 8 & Distance to dumping yard & Meter & 100 & & 300 & \\
\hline 9 & \multicolumn{6}{|c|}{ Willingness to change the present residence } \\
\hline \multirow[t]{3}{*}{$\mathbf{I}$} & Owned & No. & 20 & 66.67 & 11 & 36.67 \\
\hline & Yes & No. & 8 & 40.00 & 6 & 54.55 \\
\hline & No & No. & 12 & 60.00 & 5 & 45.45 \\
\hline \multirow[t]{3}{*}{ Ii } & Rented & No. & 10 & 33.33 & 19 & 63.33 \\
\hline & Yes & No. & 7 & 70.00 & 13 & 68.42 \\
\hline & No & No. & 3 & 30.00 & 6 & 31.58 \\
\hline \multirow[t]{3}{*}{10} & Precautionary measures fro & corporatio & to avoid $\mathrm{h}$ & ul effects & & \\
\hline & Yes & No. & 6 & 20.00 & 8 & 26.67 \\
\hline & No & No. & 24 & 80.00 & 22 & 73.33 \\
\hline
\end{tabular}


Table.3 Health impacts due to dumping of solid waste on households near dumping yard

\begin{tabular}{|c|c|c|c|c|c|c|c|c|c|}
\hline \multirow[t]{2}{*}{ Sl. No } & \multirow[t]{2}{*}{ Disease } & \multicolumn{4}{|c|}{ Hubballi-Dharwad twin cities } & \multicolumn{4}{|c|}{ Bengaluru city } \\
\hline & & Households & $\%$ & Persons & $\%$ & Households & $\%$ & Persons & $\%$ \\
\hline \multicolumn{2}{|c|}{ 1. Adults } & 18 & 60.00 & 22 & 47.83 & 21 & 70.00 & 27 & 51.92 \\
\hline a. & Asthma & 6 & 33.33 & 8 & 36.36 & 9 & 42.86 & 11 & 40.74 \\
\hline b. & Nose irritation & 5 & 27.78 & 6 & 27.27 & 5 & 23.81 & 7 & 25.93 \\
\hline c. & Respiratory problem & 7 & 38.89 & 8 & 36.36 & 7 & 33.33 & 9 & 33.33 \\
\hline \multicolumn{2}{|c|}{ Average expenditure on health ( $₹ /$ month) } & \multicolumn{4}{|c|}{156} & \multicolumn{4}{|c|}{180} \\
\hline \multicolumn{2}{|c|}{ 2. Children } & 21 & 70.00 & 24 & 52.17 & 20 & 66.67 & 25 & 48.08 \\
\hline a. & Omitting & 12 & 57.14 & 13 & 54.17 & 10 & 50.00 & 12 & 44.00 \\
\hline b. & Fever & 7 & 33.33 & 9 & 37.50 & 8 & 40.00 & 10 & 32.00 \\
\hline c. & Malaria & 2 & 9.52 & 2 & 8.33 & 2 & 10.00 & 3 & 24.00 \\
\hline \multicolumn{2}{|c|}{ Average expenditure on health(₹/month) } & \multicolumn{4}{|c|}{171} & \multicolumn{4}{|c|}{192} \\
\hline
\end{tabular}

Table.4 Problems faced by households near dumping yard in selected municipal corporations

\begin{tabular}{|c|l|c|c|c|c|}
\hline SI.No & \multicolumn{1}{|c|}{ Problems } & \multicolumn{2}{|c|}{$\begin{array}{c}\text { Hubballi-Dharwad twin } \\
\text { cities (HDMC) }\end{array}$} & \multicolumn{2}{c|}{ Bengaluru city (BBMP) } \\
\cline { 3 - 6 } & & Garrett score & Rank & Garrett score & Rank \\
\hline $\mathbf{1}$ & Foul smell & 72.33 & I & 75.11 & I \\
\hline $\mathbf{2}$ & Smoke generation & 61.60 & II & 58.87 & III \\
\hline $\mathbf{3}$ & Mosquito problem & 58.40 & III & 60.32 & II \\
\hline $\mathbf{4}$ & Stray animals & 44.33 & IV & 43.23 & IV \\
\hline $\mathbf{5}$ & Spread of diseases & 35.07 & V & 36.56 & V \\
\hline $\mathbf{6}$ & Blockage of drainage & 27.67 & VI & 25.14 & VI \\
\hline
\end{tabular}

Dharwad district

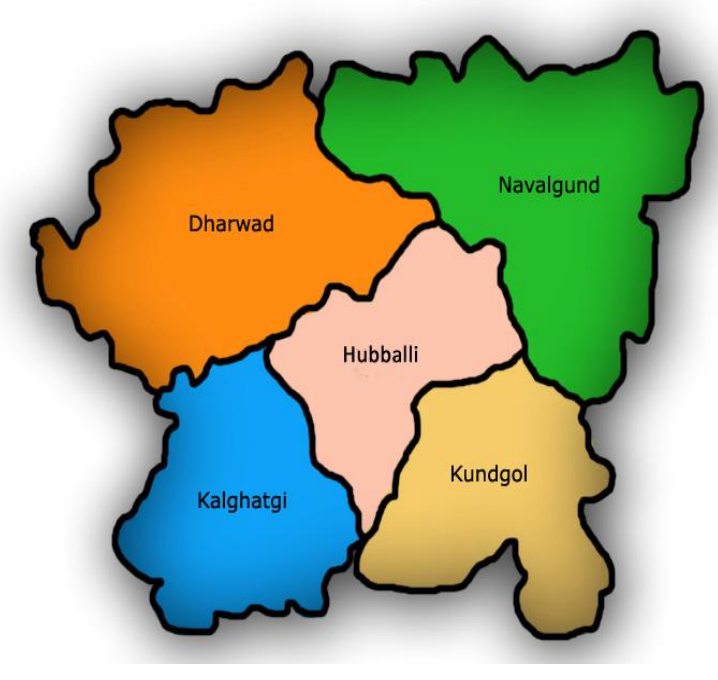

Hubballi-Dharwad municipal corporation

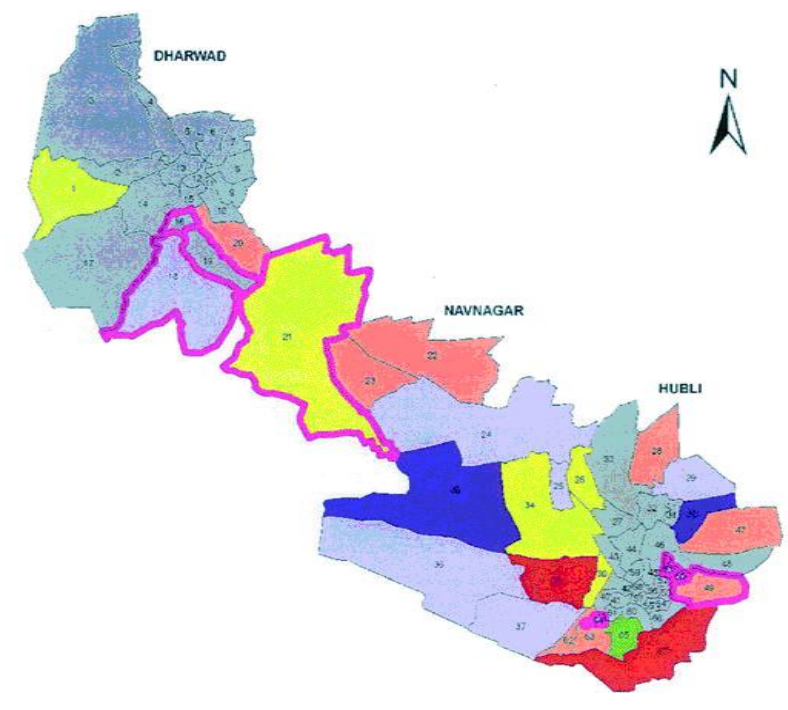




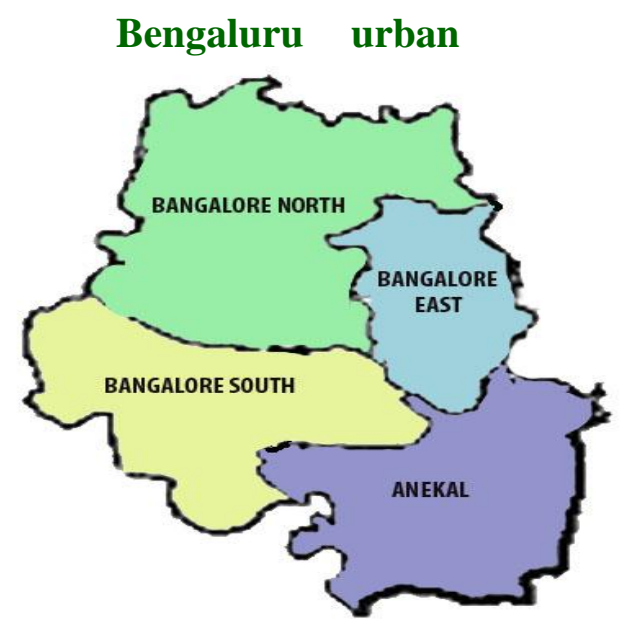

The results revealed that in Hubballi-Dharwad out of the total 30 selected households, in almost 60 per cent (18) households, where the adults had a health related negative impacts like asthma, nose irrigation and respiratory problems. The number of persons affected by these health problems was 21 and a majority of the persons $(36.36 \%)$ had a problem of asthma and respiratory problem followed by nose irritation (27.27 \%). The average monthly expenditure towards treatment of health related ailments was invariably had to be incurred and was ₹156. Total number of children affected by various health problems was 24 and those were from $21(70.00 \%)$ households. Among the health problems, frequent omitting was the common health related problems noticed in case of children $(57.14 \%)$. The remaining 33.33 per cent and 9.52 per cent of the children were suffered from frequent fever and malaria. In Bangalore city, the number of adult and children affected by health problems was more compared to Hubballi-Dharwad. A total of 27 adults from $21(70.00 \%)$ households and 25 children from 20 (66.67 \%) households had health problems. Among the adults, 40.74 per cent of the adults had asthma while 25.93 per cent and 33.33 per cent had nose irritation and respiratory problems, respectively. Out of the 30 selected households, as high as 66.67 per cent households witnessed one or the other health related problems like omitting $(50.00 \%)$, fever $(40.00 \%)$ and malaria $(10.00 \%)$. The average monthly health expenditure for adults

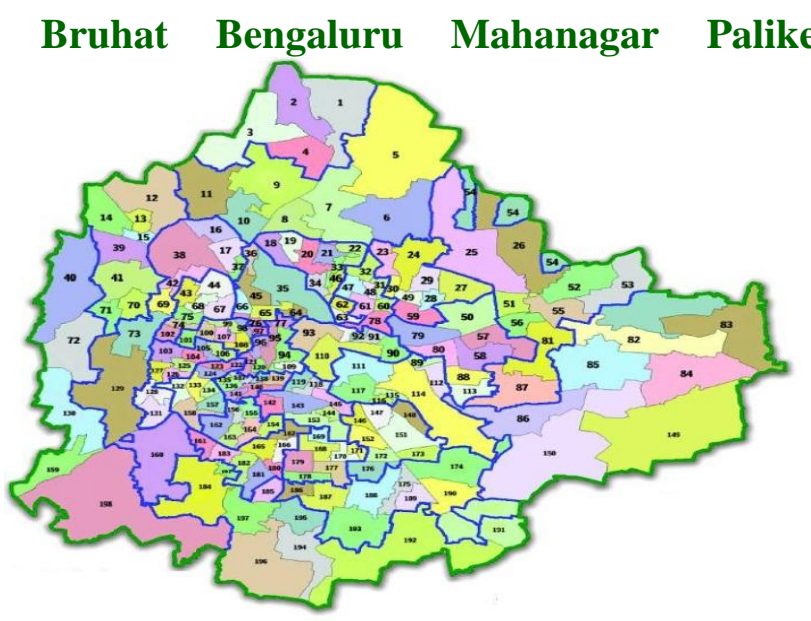

and children was ₹ 180 and ₹ 192, respectively. The study showed that continuous exposer to hazardous waste near dumping sites had invariably resulted into human health problems, children were the most vulnerable groups to these diseases. Similar observations were made by Sankoh et al., (2013) they reported that both nearby residents and far away residents suffered from related diseases such as malaria, chest pain, diarrhea and cholera due to location of the dumping sites closer to their settlements.

\section{Problems faced by households near dumping yard}

Based on the review of literature and opinion from respondents major problems faced by them due to improper or unscientific disposal of solid waste were considered for ranking. The respondents were asked to rank the problems in a scale of one to six, the least score being sixth rank and highest score for rank one. These ranked problems were analyzed using garrett ranking technique which gives the garretts score for each problem and based on these scores the severity of the problem was designated. The ranks indicated severity of the particular health problem near dumping yards both in HubballiDharwad and Bengaluru. The results of the analysis are furnished in Table 4. In the ranking method, foul smell was the foremost problem faced by the households and ranked first with mean garret score of 72.33 in HubballiDharwad and was on par at 75.11 in Bengaluru. 
The second and third rank was given to continues smoke generation (GS: 61.60) and mosquito problem (GS: 58.40) in HubballiDharwad, respectively. In Bengaluru, problems like mosquito (GS: 60.32) menace and smoke generation (GS: 58.87) ranked second and third, respectively. Both in Hubballi-Dharwad and Bengaluru cities the problems like spread of diseases and blockage of drainage canals were ranked fifth and six. The problem of stray animals was ranked fourth both in HubballiDharwad and Bengaluru with a garrett score of 44.33 and 43.23, respectively. Subhash (2010) in his study made an attempt to know the environmental problem due to solid waste in different locality. Majority of respondents felt that there was a permanent spreading of garbage and the problem of air pollution in terms of burning of waste and emission of bad smell was realized by the respondents.

In conclusion, the present level of solid waste management and its disposal pattern adopted mainly open dumping in both the cities could be very well said that such sites are serving as potential threat to public health and have polluted the environment. Breathing of bioaerosols, and of smoke and fumes produced by open burning of waste caused many health related problems among residents especially near dumping yards. Open-dumping of solid waste is not advisable as it caused various illeffects both on environment and public health through air, water and soil pollution. In Hubballi-Dharwad, disposal method adopted was open dumping for many decades which considered as the most unhygienic to people residing near dumping yards and also to the environment in the vicinity. In Bengaluru, landfilling of solid waste was practiced however was found to be unscientifically carried thus, creating public health hazardous on the habitats. The long term exposure of population who resided in the area surrounding dumping sites has led to negative health impacts on people. Therefore, open dumping of solid waste needs to be stopped and the arrangements for sanitary landfilling which is considered to be safe method and needs to be adopted by HDMC. Further, the practice of landfilling could be restricted only to the inert and other waste that are not suitable either for recycling and biological processing in both the corporations.

\section{References}

Arivukkarasu, D. and Lakshmi, T. S., 2014, An exploratory study on municipal solid waste management system and energy recovery in Tiruvallur, India. Int. J. Innov. Res. Sci., Eng. Technol., 3(1):5458.

Ramachandra, T. V., 2009, Management of Municipal Solid Wastes, TERI Press, New Delhi, pp.1-250.

Chattopadhyay, S., Dutta, A. and Ray, S., 2009, Municipal solid waste management in Kolkata, India.Waste Manage., 29(3):1449-1458.

Lakshmikantha, H., 2006, Report on waste dump sites around Bangalore. Waste Manag., 26(6):640-50.

Sankoh, F. P., Xiangbin, Y. and Alhaji, M. H., 2012, A situational assessment of socioeconomic factors affecting solid waste generation and composition in Freetown, Sierra Leone. J. Environ. Prot., 3(2):563568.

Subhash, A., 2010, Solid waste management. A Mittal Publication, New Delhi, India.

\section{How to cite this article:}

Shilpa P. Chowti, G.N. Kulkarni and Manjunatha, M.V. 2018. Impact of Dumping of Municipal Solid Waste on Households Near Dumping Yard in Karnataka, India. Int.J.Curr.Microbiol.App.Sci. 7(08): 924-933. doi: https://doi.org/10.20546/ijcmas.2018.708.105 